\title{
The effects of ryegrass varieties differing in soluble sugar content on the rumen fermentation of amino acids and consequences for milk flavour chemistry
}

\author{
M.H. TAVENDALE ${ }^{1}$, D. PACHECO ${ }^{1}$, G.A. LANE ${ }^{1}$, K. FRASER ${ }^{1}$, A.F. DEATH ${ }^{1}$, J.L. BURKE 2 , \\ M.J. HICKEY ${ }^{1}$ and G.P. COSGROVE ${ }^{1}$ \\ ${ }^{1}$ AgResearch, Grasslands Research Centre, PB 11008, Palmerston North \\ ${ }^{2}$ Institue of Veterinary, Animal and Biomedical Sciences, Massey University, \\ PB 11222, Palmerston North \\ michael.tavendale@agresearch.co.nz
}

\begin{abstract}
A comparative study of cows grazing grasses differing in soluble sugar content was undertaken to explore whether sugar content improves ruminal plant protein utilisation and influences milk flavour chemistry. Lower concentrations of ammonia, and amino-acid degradation products including the flavour compounds skatole and indole were observed for rumen contents sampled from non-lactating fistulated cows grazing high sugar ryegrass relative to samples from cows grazing Italian or a standard perennial ryegrass, suggesting improved plant protein nitrogen utilisation in response to the high sugar grass diet. Concentrations of plant protein fermentation products in the rumen of the fistulated cows were significantly higher at noon, compared to morning and afternoon values. In milk collected twice daily from the lactating cows grazing the above ryegrass varieties, no differences in yields of milkfat or skatole were detected between cows fed the different grass varieties. However yields of skatole in milkfat were two times higher in afternoon than morning milk. The rumen response to morning feeding appears to influence the flavour chemistry of afternoon milk.
\end{abstract}

Keywords: rumen metabolites, milkfat skatole, indole, perennial ryegrass, Italian ryegrass, water soluble carbohydrate

\section{Introduction}

Skatole (3-methylindole) and indole are aroma compounds which impart a high sensory impact in dairy products. These compounds occur at elevated concentrations in milk from cows grazing pasture compared with those fed concentrates (Bendall 2001; Lane et al. 2002). They are formed in the rumen from microbial degradation of the amino acid tryptophan (Tavendale et al. 2005) and this process is favoured by higher concentrations and intake of dietary proteins relative to readily digestible carbohydrate (Kebreab et al. 2002). Forages high in readily degradable protein content have been shown to favour the formation in the rumen of skatole and indole, together with ammonia and other amino-acid derived compounds including branched-chain volatile fatty acids (isobutyric and isovaleric acid) and $p$-cresol (Schreurs et al. 2003, 2006; Fraser et al. 2004).

In the UK it has been shown that ryegrasses selected for high sugar content improve ruminal amino acid utilisation for microbial protein synthesis by providing a better supply of water soluble carbohydrates during the peak period of plant protein fermentation (Moorby et al. 2006; Lee et al. 2002). A consequent reduction in the formation of amino acid degradation products in the rumen and their transfer to milk might be expected.

A study was undertaken to compare the effects of ryegrass varieties differing in soluble sugar content on rumen digestion of amino acids using fistulated nonlactating cows. Rumen samples were collected from non-lactating cows grazing three contrasting varieties of ryegrass at three times during the day. Measurements of milk samples collected in the morning and afternoon from a parallel study of lactating cows grazing the same three ryegrass varieties over a 6 -week period provide supporting data on the fate of skatole and indole following absorption from the rumen.

\section{Material and Methods}

Seven ha each of a UK 'high-sugar' perennial ryegrass (Lolium perenne, L) (HS, cv. AberDart), an Italian ryegrass (I, Lolium multiflorum, cv. Grasslands Moata) and a standard NZ perennial ryegrass (S, cv. Impact), were sown as grass monocultures in autumn 2004 at Massey University No. 4 dairy farm, near Palmerston North. These pastures formed part of a larger study examining lactation performance of cows grazing ryegrasses differing soluble sugar content. The study reported here used two groups of cows. Nine nonlactating, mature rumen-fistulated cows (three per treatment) were used to collect samples of rumen contents. Thirty lactating cows (10 per treatment) were used to provide data on milk yield and composition and samples of milk for analyses. Each group of cows grazed one variety of grass during the period October-December, 2004. Lactating cows were given a fresh break of pasture twice daily at an allowance of $54 \mathrm{~kg} \mathrm{DM} / \mathrm{cow}$ per day. The fistulated cows were also given fresh breaks twice daily at approximately $36 \mathrm{~kg} \mathrm{DM} /$ cow per day. 
Table 1 The chemical composition of high sugar (HS) Italian (I) and standard (S) ryegrass offered to lactating and non-lactating dairy cows.

\begin{tabular}{|c|c|c|c|c|c|c|c|}
\hline & \multicolumn{2}{|c|}{ - HS } & \multicolumn{2}{|c|}{-1} & \multicolumn{2}{|c|}{$\mathrm{S}$} & \multirow[b]{2}{*}{ SD } \\
\hline & am & $\mathrm{pm}$ & am & $\mathrm{pm}$ & am & $\mathrm{pm}$ & \\
\hline ADF & 24.3 & 23.2 & 23.1 & 24.0 & 24.1 & 23.1 & 2.29 \\
\hline NDF & 49.5 & 45.4 & 48.2 & 47.2 & 51.9 & 46.8 & 4.90 \\
\hline SSS & 19.1 & 23.5 & 21.0 & 24.6 & 14.1 & 20.6 & 4.43 \\
\hline Protein & 19.2 & 18.8 & 20.6 & 18.8 & 24.2 & 21.7 & 2.72 \\
\hline Lignin & 1.4 & 0.9 & 1.1 & 1.0 & 0.7 & 0.9 & 1.29 \\
\hline Lipid & 3.9 & 3.9 & 4.0 & 3.9 & 4.1 & 4.2 & 0.41 \\
\hline Ash & 8.5 & 8.0 & 9.3 & 8.1 & 10.0 & 9.3 & 1.03 \\
\hline
\end{tabular}

Mean value presented, $\mathrm{n}=12$ for each grass $\mathrm{x}$ time treatment am: $0800 \mathrm{~h}, \mathrm{pm}: 1600 \mathrm{~h}, \mathrm{SD}=$ pooled standard deviation.

Units: \% dry matter ADF: acid detergent fibre; NDF: neutral detergent fibre; SSS soluble sugars and starch. Feed composition values are predicted from NIRS analysis and calibrations. Lignin NIR calibration based on acid detergent lignin.

\section{Rumen chemistry}

Rumen samples were collected at $0800 \mathrm{~h}, 1200 \mathrm{~h}$ and $1600 \mathrm{~h}$ from the nine non-lactating, mature rumenfistulated cows (three per treatment) on 2 consecutive days, 11 and 12 November, after a 2 week adaptation to grazing ad libitum HS, I or S. Rumen contents were squeezed though two layers of cheese cloth and subsampled for ammonia concentrations by flow injection analysis and volatile fatty acid (VFA) concentrations by gas chromatography as described by Attwood et al. (1999) and $p$-cresol, skatole and indole concentrations by simultaneous distillation extraction and gas chromatograph mass spectroscopy as described by Lane \& Fraser (1999).

\section{Milk chemistry}

Parallel to the rumen study, milk samples from 30 cows (10 per grass variety) grazing HS, I, or S grasses were collected over two consecutive milkings (afternoon, PM and the following morning, AM) twice weekly for 6 consecutive weeks commencing 28 October, 2004. Milk yields were recorded and milk samples analysed for milk fat (Fourier Transform infrared analyser, Livestock Improvement Corporation, Hamilton). The milk samples from individual cows within each treatment group (grass $\mathrm{x}$ milking time) were pooled, centrifuged at $10,000 \mathrm{~g}$ for $30 \mathrm{~min}$, to provide a milkfat sample for skatole and indole analysis by high performance liquid chromatography coupled with fluorescence detection (Lane et al. 2002).

\section{Pasture sampling}

Samples of grass were collected at $0800 \mathrm{~h}$ (AM) and $1600 \mathrm{~h}$ (PM), twice weekly during the course of this study coinciding with dates of milk sampling. The samples were hand plucked from the break of grass about to be allocated to each group of cows to represent herbage being eaten. Samples were immediately frozen in liquid nitrogen, and stored frozen for subsequent freeze drying and grinding and analysis using near-infrared reflectance spectroscopy (NIRS) (Feedtech, AgResearch).

\section{Statistical methods}

Statistical analysis was performed on the rumen and milk chemistry data using the MIXED procedure from SAS v. 9.1 (2003). The models included time of the day $(0800$ h, $1200 \mathrm{~h}, 1600 \mathrm{~h}$ or AM, PM for rumen and milk samples respectively) and grass variety as main effects plus their interactions. Repeated measurements were accounted for using the REPEATED statement. Multivariate ANOVA on pasture composition variables was performed using the procedure GLM of SAS, with the MANOVA option. The multivariate model included treatment, time and their interactions.

\section{Results}

\section{Feed composition}

For each grass variety, the soluble sugars, starch and neutral fibre content was higher and the crude protein content lower in PM samples than in AM samples (Wilks' Lambda test: $\mathrm{P}<0.001$ ) (Table 1). Standard ryegrass had significantly higher content of protein and ash and lower soluble sugars and starch than I or HS grasses (Wilks' Lambda test: $\mathrm{P}<0.001)$. Italian ryegrass was more variable in soluble sugar and starch content compared to the HS or $\mathrm{S}$ grasses.

\section{Rumen chemistry}

For each grass treatment, the rumen concentrations of the VFAs (acetic, propionic, butyric and valeric acids) increased $(\mathrm{P}<0.01) 1.3$ to 1.6 fold from $0800 \mathrm{~h}$ to 1200 $\mathrm{h}$ and remained at this elevated concentration at $1600 \mathrm{~h}$ (Table 2). There were no significant differences among grass treatments in concentration of rumen VFAs or in the propionic to acetic acid ratios. For all grass treatments, the rumen concentration of compounds derived from protein fermentation, isobutyric and isovaleric acids, $p$ cresol, skatole, indole and ammonia, increased $(\mathrm{P}<0.01)$ 1.2 to 2.8 fold from $0800 \mathrm{~h}$ to $1200 \mathrm{~h}$. By $1600 \mathrm{~h}$ the concentrations of all but skatole had declined to $0800 \mathrm{~h}$ levels. In contrast to the rumen VFAs, the peak concentrations of rumen isobutyric, and isovaleric acids, 
Table 2 The concentrations of rumen fermentation products for fistulated cows fed high sugar (HS), standard (S) and Italian (I) ryegrass.

\begin{tabular}{|c|c|c|c|c|c|c|c|c|}
\hline Compound & Time & HS & I & $\mathrm{S}$ & $\begin{array}{l}\text { SED } \\
\text { Time }\end{array}$ & $\begin{array}{c}\text { SED } \\
\text { Grass }\end{array}$ & $\begin{array}{l}\text { P time } \\
\text { effect }\end{array}$ & $\begin{array}{c}\text { P grass } \\
\text { effect }\end{array}$ \\
\hline Acetic & $\mathrm{am}$ & 60.7 & 57.4 & 56.6 & 1.849 & 2.303 & $<0.01$ & 0.12 \\
\hline \multirow[t]{2}{*}{$(\mathrm{mM})$} & noon & 79.4 & 71.1 & 75.2 & & & & \\
\hline & $\mathrm{pm}$ & 72.3 & 69.7 & 67.1 & & & & \\
\hline Propionic & $\mathrm{am}$ & 17.3 & 15.9 & 15.9 & 0.636 & 0.769 & $<0.01$ & 0.37 \\
\hline \multirow{2}{*}{$(\mathrm{mM})$} & noon & 24.3 & 22.2 & 23.7 & & & & \\
\hline & $\mathrm{pm}$ & 22.8 & 23.5 & 21.8 & & & & \\
\hline \multirow{3}{*}{ (mM) } & $\mathrm{am}$ & 11.2 & 10.4 & 9.8 & 0.422 & 0.428 & $<0.01$ & 0.01 \\
\hline & noon & 16.3 & 13.4 & 14.8 & & & & \\
\hline & $\mathrm{pm}$ & 16.2 & 16.2 & 14.7 & & & & \\
\hline \multirow{3}{*}{$\begin{array}{l}\text { Valeric } \\
(\mathrm{mM})\end{array}$} & $\mathrm{am}$ & 0.99 & 0.97 & 0.98 & 0.052 & 0.058 & $<0.01$ & 0.38 \\
\hline & noon & 1.64 & 1.42 & 1.59 & & & & \\
\hline & $\mathrm{pm}$ & 1.38 & 1.37 & 1.36 & & & & \\
\hline \multicolumn{9}{|c|}{ Protein derived } \\
\hline Isobutyric & $\mathrm{am}$ & 0.84 & 1.01 & 1.2 & 0.043 & 0.066 & $<0.01$ & $<0.01$ \\
\hline \multirow{2}{*}{$(\mathrm{mM})$} & noon & 1.07 & 1.21 & 1.4 & & & & \\
\hline & $\mathrm{pm}$ & 0.88 & 0.98 & 1.11 & & & & \\
\hline Isovaleric & $\mathrm{am}$ & 1.04 & 1.19 & 1.59 & 0.074 & 0.104 & $<0.01$ & $<0.01$ \\
\hline \multirow[t]{2}{*}{$(\mathrm{mM})$} & noon & 1.42 & 1.57 & 1.97 & & & & \\
\hline & $\mathrm{pm}$ & 1.06 & 1.2 & 1.55 & & & & \\
\hline$p$-cresol & $\mathrm{am}$ & 4.06 & 6.24 & 11.0 & 0.975 & 1.001 & $<0.01$ & $<0.01$ \\
\hline \multirow[t]{2}{*}{$(\mu \mathrm{g} / \mathrm{ml})$} & noon & 9.42 & 13.7 & 17.3 & & & & \\
\hline & $\mathrm{pm}$ & 4.40 & 7.47 & 9.00 & & & & \\
\hline Skatole & $\mathrm{am}$ & 0.66 & 1.23 & 1.40 & 0.173 & 0.213 & $<0.01$ & $<0.01$ \\
\hline \multirow[t]{2}{*}{$(\mu \mathrm{g} / \mathrm{ml})$} & noon & 2.28 & 3.33 & 3.62 & & & & \\
\hline & $\mathrm{pm}$ & 1.79 & 2.43 & 2.92 & & & & \\
\hline Indole & $\mathrm{am}$ & 0.42 & 0.68 & 1.05 & 0.134 & 0.171 & $<0.01$ & $<0.01$ \\
\hline \multirow[t]{2}{*}{$(\mu \mathrm{g} / \mathrm{ml})$} & noon & 1.13 & 2.23 & 2.07 & & & & \\
\hline & $\mathrm{pm}$ & 0.31 & 0.92 & 0.82 & & & & \\
\hline \multirow{3}{*}{$\begin{array}{l}\text { Ammonla } \\
(\mu \mathrm{g} / \mathrm{ml})\end{array}$} & $\mathrm{am}$ & 56.73 & 82.78 & 98.5 & 10.091 & 13.661 & $<0.01$ & 0.01 \\
\hline & noon & 78.82 & 134.5 & 136.3 & & & & \\
\hline & $\mathrm{pm}$ & 40.9 & 84.4 & 86.6 & & & & \\
\hline
\end{tabular}

Mean value presented, $\mathrm{n}=6$ for each grass $\mathrm{x}$ time treatment

am: 0800 h, noon: 1200 h, pm: 1600 h, P grass $x$ time effects $>0.05$ for all compounds

Table 3 The yield of milk, fat, skatole and indole at morning and afternoon milking from cows fed high sugar (HS), Italian (I) and standard (S) ryegrass.

\begin{tabular}{llccccccc}
\hline & & HS & I & S & $\begin{array}{c}\text { SED for } \\
\text { grass }\end{array}$ & $\begin{array}{c}\text { SED for } \\
\text { time }\end{array}$ & $\begin{array}{c}\text { P grass } \\
\text { effect }\end{array}$ & $\begin{array}{c}\text { P time } \\
\text { effect }\end{array}$ \\
\hline Fat $(\mathrm{kg})$ & am & 0.57 & 0.56 & 0.57 & 0.031 & 0.031 & 0.861 & $<0.001$ \\
& pm & 0.45 & 0.48 & 0.46 & & & & \\
Skatole $(\mu \mathrm{g})$ & am & 25.2 & 20.5 & 24.0 & 1.31 & 1.31 & 0.634 & $<0.001$ \\
& pm & 44.7 & 39.1 & 35.4 & & & & \\
\multirow{2}{*}{ Milk yiele $(\mu \mathrm{g})$} & am & 11.0 & 6.9 & 13.5 & 1.36 & 1.36 & 0.019 & 0.304 \\
& pm & 15.1 & 8.5 & 13.3 & & & & \\
& am & 13.6 & 14.1 & 13.2 & 0.73 & 0.73 & 0.415 & $<0.001$ \\
& pm & 8.0 & 8.4 & 7.9 & & & & \\
\hline
\end{tabular}

Mean value presented, $n=12$ for each grass $x$ time treatment. Samples represent pooled milk from 10 cows per grass $\mathrm{x}$ time treatment. $\mathrm{P}$ grass $\mathrm{x}$ time effects $>0.05$ for all compounds.

and $p$-cresol, skatole, indole and ammonia were significantly $(\mathrm{P}<0.01)$ lower for cows grazing the HS ryegrass than for cows grazing I or $\mathrm{S}$ ryegrass.

\section{Milk flavour chemistry}

Milk and milkfat yields did not differ between ryegrass treatments. The yield of skatole was 1.7 fold higher at PM than AM milking (Table 3). No differences in skatole yields were detected among the grass varieties. Indole yields did not differ between PM and AM milking but were higher for HS and S than for I ryegrass. 


\section{Discussion}

This study presents the pattern of accumulation and disappearance of rumen fermentation products between morning and afternoon milking in cows grazing ryegrass pastures ad libitum.

The pattern of an initial increase and subsequent decline in ruminal concentrations of ammonia, following feeding in the morning, contrasts with the rise in ruminal concentrations of VFAs to a plateau in the afternoon. Comparable observations were reported by Lee et al. (2002) for fistulated steers fed cut pasture indoors in the morning. Kolver et al. (1998) also reported a similar pattern of rumen ammonia formation in the morning when fistulated dairy cows were fed fresh cut pasture prior to concentrate supplementation. In the current study, the pattern observed for ammonia is similar to that for other protein amino acid-derived metabolites including skatole, indole, $p$-cresol, and isobutyric and isovaleric acids confirming there is a period favouring amino acid fermentation in the rumen when cows graze ryegrass early in the morning.

This may be a consequence of the dynamics of ryegrass digestion. When ryegrass is ingested, the protein is released more rapidly than the major energy yielding fibre-derived carbohydrates (Boudon \& Peyraud 2001). For the first grazing bout following the morning milking, ryegrass is ingested into a fairly empty rumen. Thus amino acids derived from plant protein fermentation will be released into an environment that initially has a limited supply of energy, insufficient for rumen microbes to efficiently utilise amino acids for microbial protein synthesis. This may account for the observed accumulation during the morning of products of microbial fermentation of amino acids in the rumen.

The HS and I ryegrass contained slightly, but significantly, higher concentrations of soluble sugars and starch relative to $\mathrm{S}$ ryegrass. However the rumen concentrations of ammonia, isobutyric, isovaleric, $p$ cresol, skatole and indole were lower in non-lactating fistulated cows grazing HS ryegrass compared with those grazing I or S ryegrass treatments. While the difference between the two perennial ryegrasses HS and $\mathrm{S}$ may be attributed to differences in soluble sugar and protein content resulting in reduced degradation of protein derived amino acids, other factors such as plant digestion kinetics may account for the difference between HS and I.

The differences in rumen metabolites attributed to differences among grass varieties were not reflected in the milk of the lactating cows. No detectable differences in milk skatole yields among ryegrass varieties were observed but indole yields were lower for cows fed I. Factors other than rumen metabolite formation are evidently involved.
The cause of the significantly higher yield of skatole in PM milk than in AM milk is not clear from this trial. It may derive from differences in rumen degradation of tryptophan during the intervals between milkings. The lower soluble sugar content of pasture in the morning than in the afternoon may have resulted in greater rumen degradation of amino acids in the morning. Also, as suggested by the data of Lee et al. (2002) and Kolver et al. (1998), there may have been less degradation of amino acids of ryegrass ingested during the latter part of the day. The energy content of the grass was higher, and the rumen would also be well supplied with carbohydrates from the degrading fibre ingested during the morning, with consequently less ruminal formation of skatole and indole. Thus the transient accumulation of skatole and indole in the rumen after morning feeding may be the source of differences in the flavour chemistry of milk collected in the morning and afternoon. However no direct evidence of concentrations of rumen metabolites in the period between afternoon and morning milking is available as measurements were not practical with grazing cows in this trial

Indole yields were not significantly higher in PM than in AM milk. The rumen data suggest that indole is cleared more rapidly than skatole from the rumen as concentrations of indole had reverted to morning levels at the end of the afternoon, while skatole levels remained elevated. Indeed the relative metabolic clearance rates of indole and skatole from the cow may be the dominant factor in determining the yields of indole and skatole at the PM and AM milking.

The improved ruminal utilisation of protein by cows grazing the HS ryegrass diet suggested by the rumen data implies these grasses may provide environmental advantages in reducing excreted nitrogen. In terms of milk flavour, the timing of milk collection appears to be more significant than the ryegrass cultivar. If the pattern observed in this trial of lower levels of protein-derived flavour compounds in morning than in afternoon milk is general, then morning milk could be utilised by the dairy industry for creating niche dairy produce for markets sensitive to these pasture derived flavours.

\section{ACKNOWLEDGMENTS}

Jeff Yeoman for rumen and milk chemical analysis, Subathira Sivakumaran, Wilhelmina Martin and Michelle Kirk for rumen VFA and ammonia analysis. Feedtech AgResearch, for feed composition determined via NIRS. Assistance from the staff of Massey University Agricultural Services and the No 4 Dairy Unit with trial planning and conduct is greatly appreciated. Funding for this research was provided from Dairy InSight and the Foundation for Research Science and Technology. Seed of the proprietary cultivars of perennial ryegrass was 
kindly donated by Germinal NZ Ltd and NZ Agriseeds Ltd.

\section{REFERENCES}

Attwood, G.T.; Klieve, A.V.; Ouwerkerk, D.; Patel, B.K.C. 1998. Ammonia-hyper producing bacteria from New Zealand ruminants. Applied and Environmental Microbiology 64: 1796-1804.

Bendall, J.G. 2001. Aroma compounds of fresh milk from New Zealand cows fed different diets. Journal of Agricultural and Food Chemistry 49: 4825-4832.

Boudon, A.; Peyraud, J.L. 2001. The release of intracellular constituents from fresh ryegrass (Lolium perenne $\mathrm{L}$.) during ingestive mastication in dairy cows: effect of intracellular constituents, season and stage of maturity. Animal Feed Science and Technology 93: 229-245.

Fraser, K.; Lane, G.A.; Schreurs, N.M.; Keogh, R.G.; Tavendale, M.H.; Kirk, M.; McNabb, W.C. 2004. Formation and excretion of phenol flavour compounds in sheep. Proceedings of the New Zealand Society of Animal Production 64: 203-207.

Kebreab, E.; France, J.; Mills, J.A.N.; Allison, R.; Dijkstra, J. 2002. A dynamic model of N metabolism in the lactating dairy cow and an assessment of impact of $\mathrm{N}$ excretion on the environment. Journal of Animal Science 80: 248-259.

Kolver, E.; Muller, L.D.; Varga, G.A.; Cassidy, T.J. 1998. Synchronization of ruminal degradation of supplementary carbohydrate with pasture nitrogen in lactating dairy cows. Journal of Dairy Science 81: 2017-2028.

Lane, G.A.; Fraser K. 1999. A comparison of phenol and indole flavour compounds in fat, and of phenols in urine of cattle fed pasture or grain. New Zealand Journal of Agricultural Research 42: 289-296.

Lane, G.A.; Fraser, K.; Kolver, E.S.; Rowan, D.D.; Allen.
J.M.; Mills, O.E.; Abraham A.S.; Olney, S.D. 2002. Effect of a Total Mixed Ration diet on the concentration of amino acid-derived volatiles in milk. Proceedings of the New Zealand Society of Animal Production 62: 242-245.

Lee, M.R.F; Harris, L.J.; Moorby J.M.; Humphreys, M.O.; Theodorou, M.K.; MacRae, J.C.; Scollan N.D. 2002. Rumen metabolism and nitrogen flow to the small intestine in steers offered Loium perenne containing different levels of water soluble carbohydrate. Animal Science 74: 587-596.

Moorby, J.M.; Evans, R.T.; Scollan, N.D.; MacRae, J.C.; Theodorou M.K. 2006. Increased concentration of water-soluble carbohydrate in perennial ryegrass (Lolium perenne L.). Evaluation in dairy cows in early lactation. Grass and Forage Science 61: 52-59.

SAS, 2003. SAS User's Guide. SAS Institute Inc. Version 9.1. Cary, NC, USA.

Schreurs, N.M.; Tavendale, M.H.; Lane, G.A.; Barry, T.N.; Marotti, D.M.; McNabb, W.C. 2003. Postprandial indole and skatole formation in the rumen when feeding white clover, perennial ryegrass and Lotus corniculatus. Proceedings of the New Zealand Society of Animal Production Conference 63: 14-17.

Schreurs, N.M.; Tavendale, M.H.; Lane, G.A.; Barry, T.N.; Lopez-Villalobos, N.; McNabb, W.C. 2006. Effect of different condensed tannin-containing forages, forage maturity and nitrogen fertiliser application on the formation of indole and skatole in in vitro rumen fermentations. Journal of the Science of Food and Agriculture: in press.

Tavendale, M.H.; Lane, G.A.; Schreurs, N.M.; Fraser, K.; Meagher, L.P. 2005. The effects of condensed tannins from Dorycnium rectum on skatole and indole ruminal biogenesis for grazing sheep. Australian Journal of Agricultural Research 56: 1331-1337. 